\title{
Signal transduction pathways involved in proteolysis-inducing factor induced proteasome expression in murine myotubes
}

\author{
HJ Smith' and MJ Tisdale*,1,2 \\ 'Pharmaceutical Sciences Research Institute, Aston University, Birmingham B4 7ET, UK
}

\begin{abstract}
The proteolysis-inducing factor (PIF) is produced by cachexia-inducing tumours and initiates protein catabolism in skeletal muscle. The potential signalling pathways linking the release of arachidonic acid (AA) from membrane phospholipids with increased expression of the ubiquitin-proteasome proteolytic pathway by PIF has been studied using $\mathrm{C}_{2} \mathrm{C}_{12}$ murine myotubes as a surrogate model of skeletal muscle. The induction of proteasome activity and protein degradation by PIF was blocked by quinacrine, a nonspecific phospholipase $A_{2}\left(P L A_{2}\right)$ inhibitor and trifluroacetyl $A A$, an inhibitor of cytosolic PLA $A_{2}$. PIF was shown to increase the expression of calcium-independent cytosolic PLA $\mathrm{A}_{2}$, determined by Western blotting, at the same concentrations as those inducing maximal expression of $20 S$ proteasome $\alpha$-subunits and protein degradation. In addition, both $U-73 / 22$, which inhibits agonistinduced phospholipase C (PLC) activation and D609, a specific inhibitor of phosphatidylcholine-specific PLC also inhibited PIFinduced proteasome activity. This suggests that both PLA 2 and PLC are involved in the release of AA in response to PIF, and that this is important in the induction of proteasome expression. The two tyrosine kinase inhibitors genistein and tryphostin A23 also attenuated PIF-induced proteasome expression, implicating tyrosine kinase in this process. PIF induced phosphorylation of p44/42 mitogen-activated protein kinase (MAPK) at the same concentrations as that inducing proteasome expression, and the effect was blocked by PD98059, an inhibitor of MAPK kinase, as was also the induction of proteasome expression, suggesting a role for MAPK activation in PIF-induced proteasome expression.
\end{abstract}

British Journal of Cancer (2003) 89, 1783 - 1788. doi:I0.1038/sj.bjc.660I328 www.bjcancer.com

(c) 2003 Cancer Research UK

Keywords: proteolysis-inducing factor (PIF); phospholipase $\mathrm{A}_{2}\left(\mathrm{PLA}_{2}\right)$; phospholipase $\mathrm{C}(\mathrm{PLC})$; tyrosine kinase; mitogen-activated protein kinase (MAPK); proteasome expression

Loss of muscle mass is a debilitating and life-threatening feature of cancer cachexia, as well as a number of other catabolic conditions such as sepsis, burn injury, metabolic acidosis, severe trauma and denervation atrophy. In all these conditions, muscle wasting is due to accelerated muscle protein breakdown, combined with decreased protein synthesis. The major proteolytic pathway considered to be responsible for the increased protein catabolism in skeletal muscle is the ubiquitin-proteasome proteolytic pathway (Lecker et al, 1999). In this process, proteins are marked for degradation by attachment of a polyubiquitin chain through a series of enzymes (E1, ubiquitin-activating enzyme; E2, ubiquitinconjugating enzyme; E3, ubiquitin-protein ligase) and are hydrolysed to peptides within a large $(2000 \mathrm{kDa}) 26 \mathrm{~S}$ proteasome in a process that is ATP dependent. An increased expression of proteasome subunits and $\mathrm{E} 2{ }_{14 \mathrm{k}}$ has been observed in the gastrocnemius muscle of cachectic mice (Lorite et al, 1998) and rats (Temparis et al, 1994), suggesting these elements to be important in the increased protein degradation, although recent studies (Bodine et al, 2001) suggest that $\mathrm{E} 3$ may be rate limiting in ubiquitin conjugation.

\footnotetext{
*Correspondence: Professor MJ Tisdale; E-mail: m.j.tisdale@aston.ac.uk

${ }^{2}$ Professor MJ Tisdale's current address: Department of Pharmacy, Life and Health Sciences, Aston University, Birmingham B4 7ET, UK

Received 6 May 2003; revised 20 August 2003; accepted 26 August 2003
}

We have isolated and characterised a sulphated glycoprotein (Todorov et al, 1996a), which initiates catabolism of skeletal muscle proteins both in vitro (Smith et al, 1999) and in vivo (Lorite et al, 1998), and for this reason has been called the proteolysisinducing factor (PIF). PIF is produced by the cachexia-inducing murine MAC16 tumour (Todorov et al, 1996a) as well as murine colon 26, clone 20 variant, which induces cachexia, but not by clone 5, which does not induce cachexia (Hussey et al, 2000). Proteolysis-inducing factor is produced by human carcinomas of various types (Cariuk et al, 1997) and has been correlated with a significantly greater total weight loss and rate of weight loss in patients with pancreatic carcinoma (Wigmore et al, 2000). The induction of protein catabolism by PIF was shown to be due to upregulation of the ubiquitin-proteasome pathway both in vivo and in vitro (Lorite et al, 2001), suggesting a direct effect of PIF on this pathway.

Initial studies showed that protein catabolism induced by PIF was associated with the release of arachidonic acid (AA) and the conversion to eicosanoid metabolites of which 15(S)-hydroxyeicosatetraenoic acid (15(S)-HETE) was considered to play a central role in protein degradation (Smith et al, 1999). However, the mechanism by which this occurred and the relationship with proteasome and $\mathrm{E} 22_{14 \mathrm{k}}$ expression was not determined. The most likely mechanism would involve phospholipase $\mathrm{A}_{2}\left(\mathrm{PLA}_{2}\right)$ acting on phospholipids releasing AA and a lysophospholipid, or by phospholipase C (PLC) with the formation of a diacylglycerol (DAG), followed by DAG lipase forming AA. The products of the 
PLC reaction (Nakamura and Nishizuka, 1994) as well as AA and lipoxygenase metabolites (Fan et al, 1990) are signalling molecules, which activate the protein kinase C (PKC) family of serine/ threonine kinases, which we have shown (unpublished results) to act as intracellular signals of PIF action on the proteasome. The current study investigates the role of $\mathrm{PLA}_{2}$ and PLC on PIFinduced proteasome expression as well as on potential substrates for PKC using $\mathrm{C}_{2} \mathrm{C}_{12}$ myotubes, which we have previously shown (Gomes-Marcondes et al, 2002) to be a good model for studying PIF action on the proteasome.

\section{MATERIALS AND METHODS}

\section{Materials}

Fetal calf serum (FCS), horse serum (HS) and Dulbecco's modified Eagle's medium (DMEM) were purchased from Life Technologies (Paisley, UK). Mouse monoclonal antibody to $20 \mathrm{~S}$ proteasome subunits $\alpha 1,2,3,5,6$ and 7 (clone MCP 231) were purchased from Affiniti Research Products (Exeter, UK), and rabbit polyclonal antisera to the ubiquitin-conjugating enzyme $\left(\mathrm{E} 2_{14 \mathrm{k}}\right)$ was a gift from Dr Simon Wing, McGill University, Montreal, Canada. The antibody recognises both isoforms of $\mathrm{E} 2{ }_{14 \mathrm{k}}$ encoded by HHR6A and HHR6B (Rajapurohitam et al, 1999). The HHR6B gene encodes the isoform for which mRNA levels increase in atrophying muscles. The antibody detected $\mathrm{E} 22_{14 \mathrm{k}}$ as an $M_{\mathrm{r}} 17000$ band. Mitogen-activated protein kinase (MAPK) proteins and their phosphorylated (active) forms were detected with anti-extracellular signal-regulated kinase (ERK) 1 and 2 [pTpY $\left.{ }^{185 / 187}\right]$ nonphosphospecific and phosphospecific rabbit polyclonal antisera (Biosource International, Belgium). Rabbit polyclonal antisera to $\mathrm{PLA}_{2}$, Type V1 was purchased from Calbiochem, Nottingham, UK. Sheep anti-mouse and goat anti-rabbit antisera were purchased from Dako Ltd (Cambridge, UK), while the $\beta$-tubulin mouse monoclonal antibody was obtained from Calbiochem, Nottingham, UK. The following inhibitors were also purchased from Calbiochem: quinacrine dihydrochloride, trifluoroacetylarachidonic acid, U73122, D609, genistein, tryphostin A23 and PD 98059.

\section{Cell culture}

$\mathrm{C}_{2} \mathrm{C}_{12}$ myoblasts were grown in DMEM supplemented with $10 \%$ FCS, glutamine and $1 \%$ penicillin-streptomycin in a humidified atmosphere of $10 \% \mathrm{CO}_{2}$ in air at $37^{\circ} \mathrm{C}$. Myotubes were formed by allowing confluent cultures to differentiate in DMEM containing $2 \%$ HS, with medium changes every 2 days.

\section{Purification of PIF}

PIF was purified from solid MAC16 tumours excised from mice with a weight loss between 20 and $25 \%$. Tumours were homogenised in $10 \mathrm{~mm}$ Tris- $\mathrm{HCl}, \mathrm{pH} 8.0$ containing $0.5 \mathrm{~mm}$ phenylmethylsulphonyl fluoride, $0.5 \mathrm{~mm}$ EGTA and $1 \mathrm{~mm}$ dithiothreitol at a concentration of $5 \mathrm{mlg}^{-1}$ tumour. The supernatant obtained after ammonium sulphate $\left(40 \% \mathrm{w} \mathrm{v}^{-1}\right)$ was subjected to affinity chromatography using an anti-PIF monoclonal antibody coupled to a solid matrix as described (Todorov et al, 1996a). The immunogenic fractions were concentrated and used for further studies. The only contaminant was albumin (Todorov et al, 1996b) and the PIF was used without further purification.

\section{Measurement of proteasome activity}

The 'chymotrypsin-like' enzyme activity of the proteasome was measured using the fluorogenic substrate suc-LLVY-aminomethyl coumarin $(0.1 \mathrm{~mm})$ essentially according to the method of Orino et al (1991). Myotubes were washed in ice-cold phosphate-buffered saline (PBS) and sonicated in $20 \mathrm{~mm}$ Tris- $\mathrm{HCl}, \mathrm{pH} 7.5,2 \mathrm{~mm} \mathrm{ATP,}$
$5 \mathrm{~mm} \mathrm{MgCl}_{2}$ and I mM dithiothreitol at $4{ }^{\circ} \mathrm{C}$. The supernatant formed by centrifugation at 15000 r.p.m. for $10 \mathrm{~min}$ at $4^{\circ} \mathrm{C}$ was analysed for 'chymotrypsin-like' activity using a Microplate Spectrofluorimeter (SPECTR max, Molecular Devices, CA, USA). Results were calculated as activity $\mu \mathrm{g}$ protein ${ }^{-} 1 \mathrm{~min}^{-1}$. Protein degradation in the presence of PIF was determined as previously described (Gomes-Marcondes et al, 2002).

\section{Western blot analysis}

Samples of cytosolic protein $(2.5-5 \mu \mathrm{g})$ were resolved on $10 \%$ sodium dodecylsulphate-polyacrylamide gels (SDS-PAGE) and transferred onto Hybond ${ }^{\mathrm{TM}} \mathrm{ECL}^{\mathrm{TM}}$ nitrocellulose membranes (Amersham, UK), which had been blocked with 5\% Marvel in Tris-buffered saline, $\mathrm{pH} 7.5$, at $4{ }^{\circ} \mathrm{C}$ overnight. The primary antibodies were used at a dilution of $1: 40$ ( $\beta$-tubulin); $1: 100$ $\left(\mathrm{E} 2_{14 \mathrm{k}}\right) ; 1: 500$ (anti-ERK1 and 2) or $1: 1500$ (anti-20S proteasome), while the secondary antibodies were used at a dilution of $1: 2000$. Incubation was carried out for $2 \mathrm{~h}$ at room temperature and development was by enhanced chemiluminescence (Amersham UK). Loading was quantitated either by $\beta$-tubulin or by a parallel gel, which was stained with Coomassie brilliant blue.

\section{Statistical analysis}

Results are expressed as means \pm s.e.m. Differences were determined by one-way ANOVA followed by the Tukey-Kramer multiple comparison test.

\section{RESULTS}

The effect of quinacrine, a nonspecific PLA $_{2}$ inhibitor on proteasome functional activity ('chymotrypsin-like' enzyme activity), in the presence of PIF is shown in Figure 1A. As previously reported (Gomes-Marcondes et al, 2002), PIF produced a significant increase in proteasome activity at concentrations between 2 and $10 \mathrm{~nm}$, with a peak of activity at $4 \mathrm{~nm}$, while both higher and lower concentrations had no effect. At a concentration of $5 \mu \mathrm{M}$, quinacrine completely attenuated the increase in 'chymotrypsin-like' enzyme activity in the presence of PIF (Figure 1A), as did the cytosolic PLA ${ }_{2}$ inhibitor trifluroacetyl AA (Figure 1B). This might be expected, since cytosolic PLA $\mathrm{P}_{2}$ exhibits a high selectivity towards the cleavage of unsaturated fatty acids and in particular AA (Glasser et al, 1993). Both quinacrine and trifluroacetyl AA also attenuated the PIF-induced increase in protein degradation (Figure 1C). Trifluoroacetyl AA also attenuated the increase in $20 \mathrm{~S}$ proteasome expression in the presence of PIF (Figure 2A) and the increase in calcium-independent cytosolic $\mathrm{PLA}_{2}\left(\mathrm{iPLA}_{2}\right.$ ) (Figure $2 \mathrm{~B}$ ) as detected by Western blotting.

The PIF-induced increase in 'chymotrypsin-like' enzyme activity was also inhibited by U-73122 (Figure 3A), which inhibits agonistinduced PLC activation (Yule and Williams, 1992), and D609 (Figure 3B), a selective inhibitor of phosphatidylcholine (PC)specific PLC (Sauer et al, 1984). These results suggest that both $\mathrm{PLA}_{2}$ and PLC are involved in the hydrolysis of AA from membranes of muscle cells in response to PIF, and that this is important in proteasome expression.

If PLC is involved in PIF-induced proteasome induction, this suggests that PKC may also be required for intracellular signal transduction. We have previously shown (unpublished results) that PKC is involved in PIF-induced proteasome expression and therefore the effect of two tyrosine-kinase inhibitors genistein and tryphostin A23 on PIF-induced 'chymotrypsin-like' enzyme activity was determined (Figure 4). Both genistein at a concentration of 100 and $300 \mu \mathrm{m}$ (Figure 4A) and tryphostin A23, also at a concentration greater than $100 \mu \mathrm{M}$ (Figure 4B), completely attenuated the PIF-induced increase in proteasome activity. These 
A

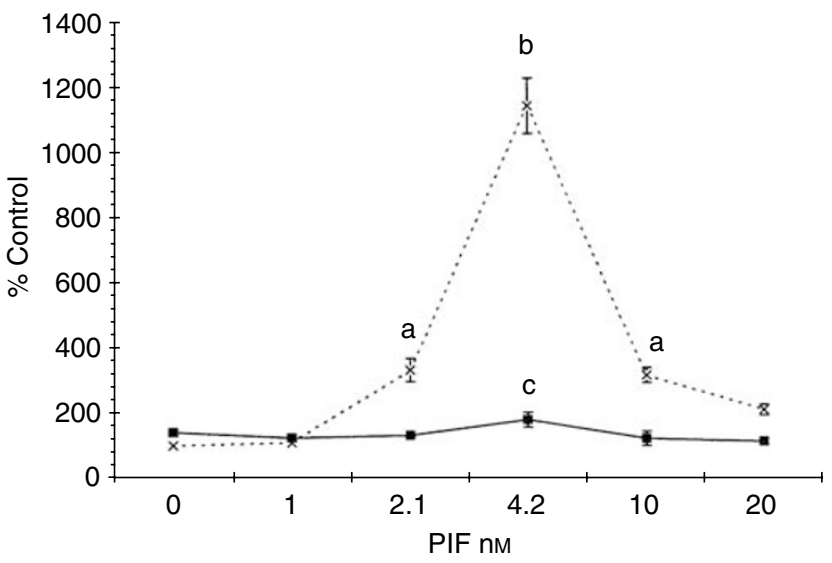

B

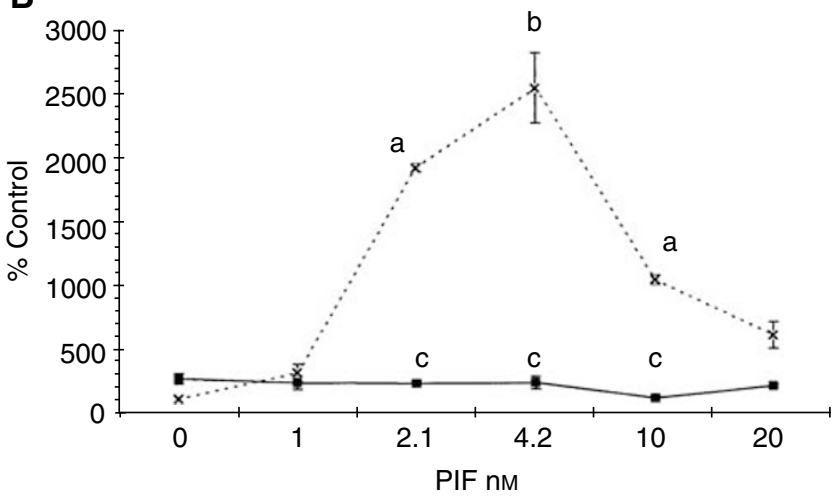

C

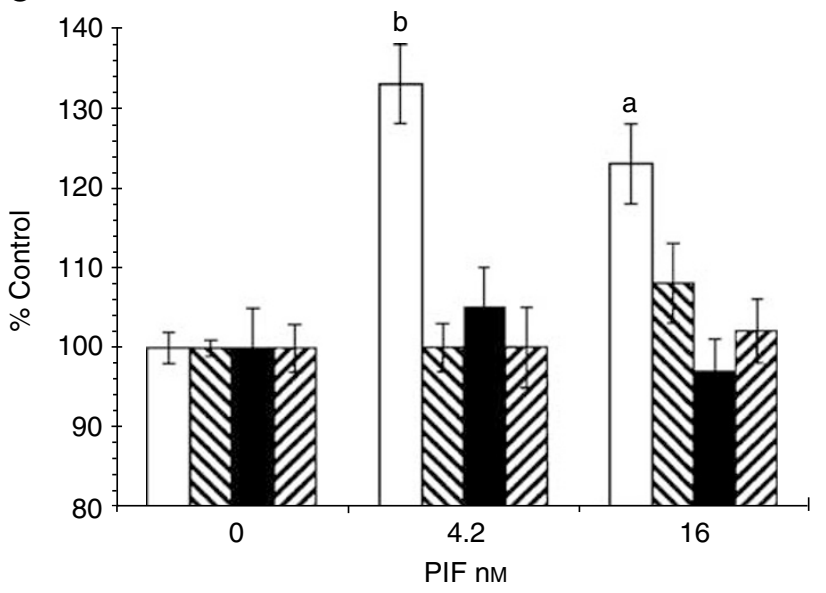

Figure I Effect of PIF concentration on the chymotrypsin-like enzyme activity of the proteasome in $\mathrm{C}_{2} \mathrm{C}_{12}$ myotubes in the absence $(x)$ and presence $(\mathbf{\square})$ of $(\mathbf{A})$ quinacrine $(5 \mu \mathrm{M})$ or $(\mathbf{B})$ trifluoroacetyl AA $(20 \mu \mathrm{M})$. (C) The effect of quinacrine $(5 \mu \mathrm{M})(\square)$, trifluoroacety I AA $(20 \mu \mathrm{M})(\mathbf{\square})$ and PD98059 $(10 \mu \mathrm{M})(\square)$ on protein degradation determined by the release of phenylalanine as previously described (Gomes-Marcondes et al, 2002) in murine myotubes in the presence of PIF. The experiments were repeated three times $(n=9)$. Differences from control are indicated as a $P<0.01$ and $b, P<0.00$ I, while differences from those in the absence of the inhibitors are indicated as $c, P<0.000 \mathrm{I}$. The inhibitors were added to the cells $2 \mathrm{~h}$ prior to PIF.

results suggest that protein tyrosine kinase is also involved in PIFinduced proteasome expression.

Activation of PKC has been shown to activate the ERK and subsequently MAPK (Toker, 1998). To investigate a role for MAPK
A
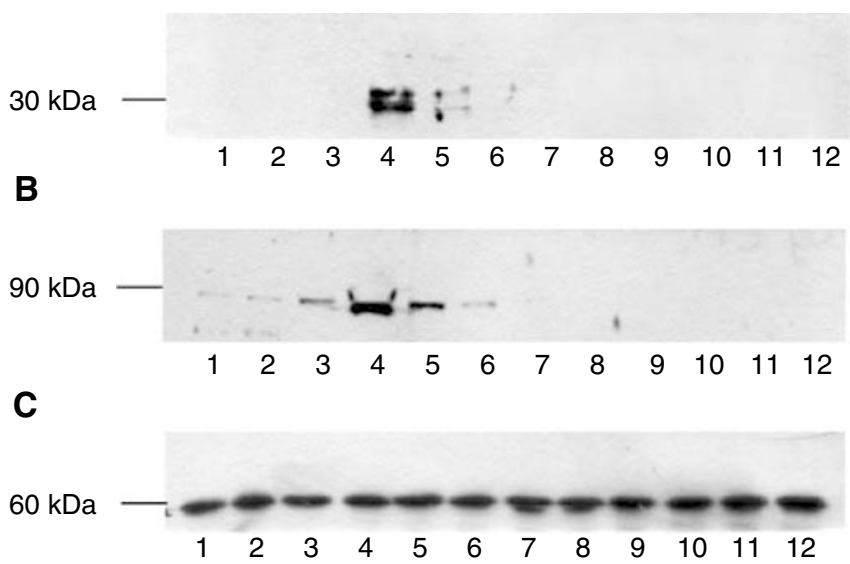

Figure 2 Western blot of soluble extracts of $\mathrm{C}_{2} \mathrm{C}_{12}$ myotubes treated with 0 (lanes I and 7); I.0 (lanes 2 and 8); 2.1 (lanes 3 and 9); 4.2 (lanes 4 and 10); 10 (lanes 5 and II) or $20 \mathrm{nM}$ PIF (lanes 6 and 12) in the absence (lanes $1-6)$ or after $2 \mathrm{~h}$ pretreatment with trifluoroacetyl AA $(20 \mu \mathrm{M})$ (lanes 7-12). Bands were detected using either antibody to 205 proteasome $\alpha$-subunits $(\mathbf{A})$, iPLA $2(\mathbf{B})$ or $\beta$-tubulin $(\mathbf{C})$. The blots shown are representative of at least three separate experiments.
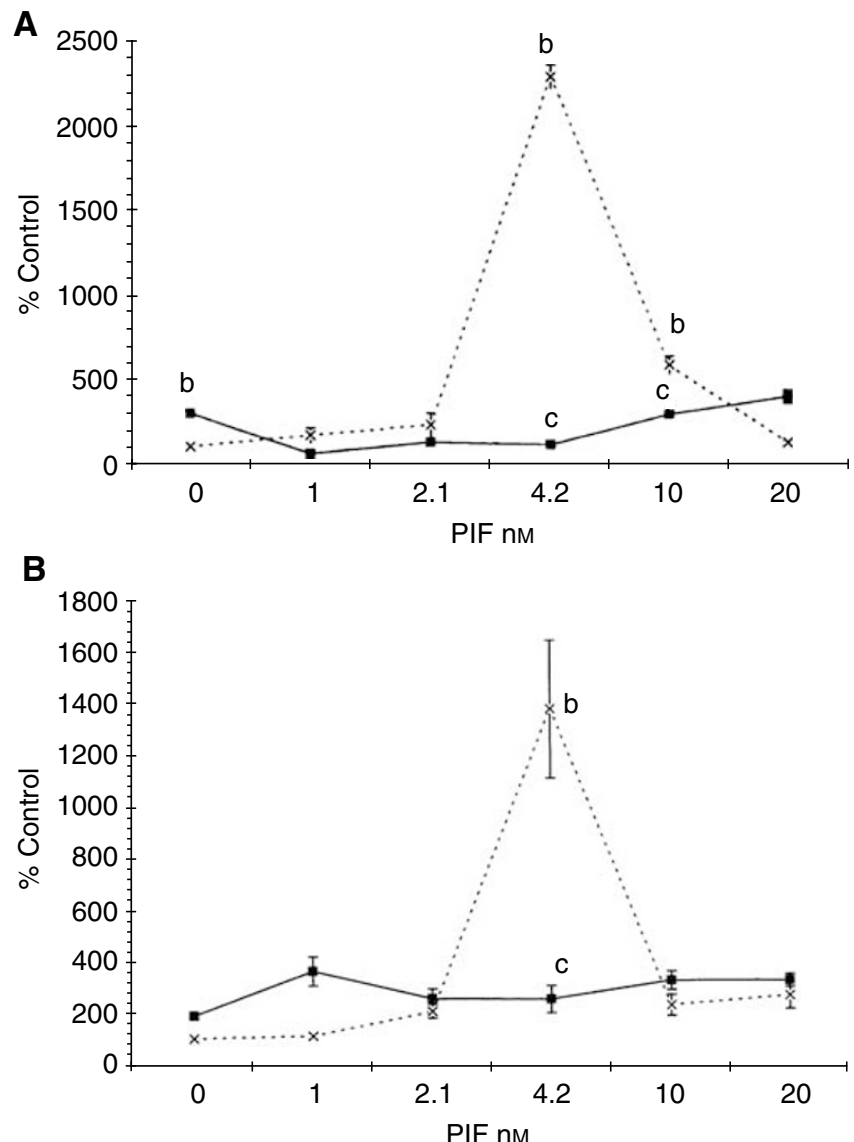

Figure 3 Effect of PIF concentration on the chymotrypsin-like enzyme activity of the proteasome in $C_{2} C_{12}$ myotubes in the absence $(x)$ or presence $(\mathbf{\square})$ of U73II (5 $\mu \mathrm{M})(\mathbf{A})$ or D609 $(200 \mu \mathrm{M})(\mathbf{B})$. The inhibitors were added to the cells $2 \mathrm{~h}$ prior to PIF. The experiment was repeated three times $(n=9)$. Differences from the control are indicated as $b$, $P<0.001$, while differences from those in the absence of inhibitors are indicated as $C, P<0.001$. 
A

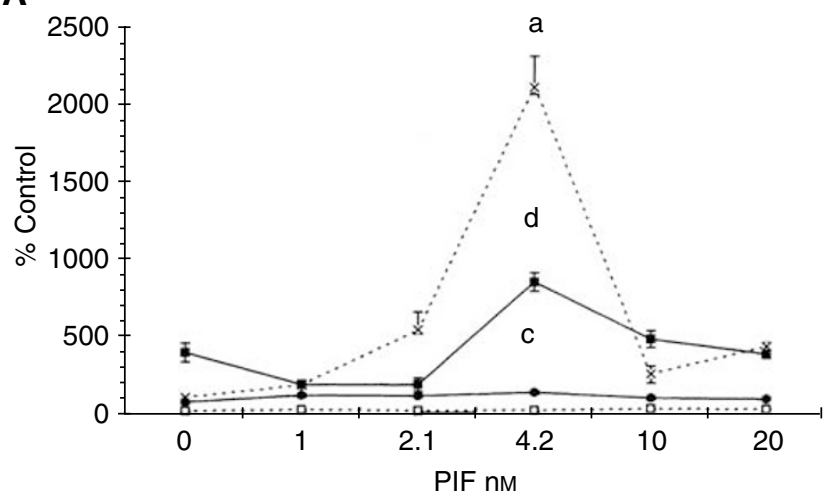

B

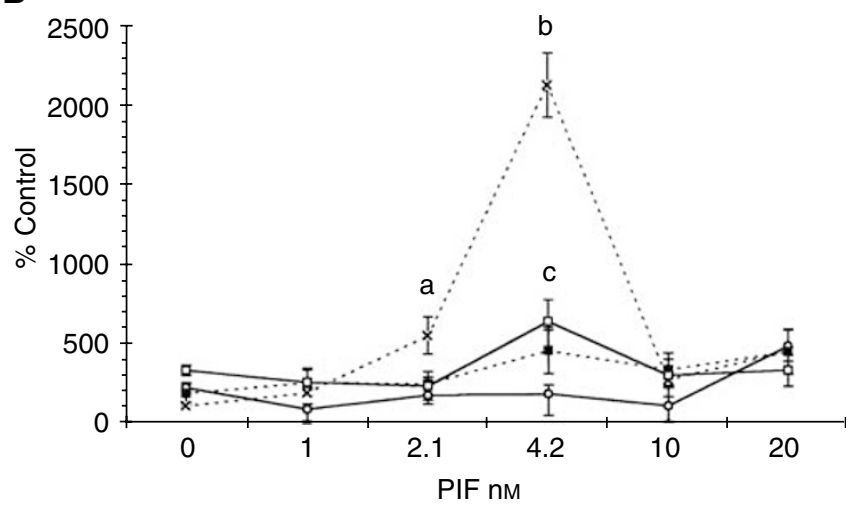

Figure 4 Effect of the concentration of PIF on the chymotrypsin-like enzyme activity in $C_{2} C_{12}$ myotubes in the absence $(x)$ or presence of genistein $30(\mathbf{\square}), 100(\mathbf{O})$ or $300(\square) \mu \mathrm{M}(\mathbf{A})$ or $30(\square), 100(\mathbf{\square})$ or 300 (O) $\mu$ M tryphostin A23 (B), where $n=9$. Differences from the control are indicated as a, $P<0.05$ and $b, P<0.005$, while differences in the presence of the inhibitor are indicated as $c, P<0.005$ or $d, P<0.05$.

in PIF-induced proteasome expression, the effect of the selective and cell-permeable inhibitor of MAP kinase kinase (MEK) PD98059 (Kültz et al, 1998) was investigated. PD98059 attenuated the PIF-induced increase in 'chymotrypsin-like' enzyme activity (Figure 5A), 20S $\alpha$-subunit expression (Figure 5B) and $E 22_{14 k}$ (Figure 5C). As shown in Figure 6A, PIF induced phosphorylation of p44/42 MAPK, while the total MAPK remained unchanged (Figure 6B). The concentration of PIF inducing a maximum phosphorylation of p44/42 MAPK (Figure 6A) (4.2 nM) was the same as that inducing proteasome expression and E2 $14 \mathrm{k}$ (Figure 5). PD98059 completely blocked PIF-induced p44/42 MAPK activation (Figure 6A) as well as proteasome expression (Figure 5), confirming a role for MAPK activation in PIF-induced proteasome expression.

\section{DISCUSSION}

Using murine myoblasts as a surrogate model of skeletal muscle, the induction of protein degradation by PIF was positively correlated with AA release and subsequent conversion to $15(S)$ HETE (Smith et al, 1999). This process was blocked by eicosapentaenoic acid, which also attenuated protein degradation by PIF, both in vitro (Smith et al, 1999) and in vivo (Hussey and Tisdale, 1999). These observations suggest that the formation of eicosanoids from AA was important in PIF-induced protein catabolism, mediated through the upregulation of the ubiquitinproteasome proteolytic pathway (Lorite et al, 2001). Despite the importance of the ubiquitin-proteasome pathway, very little is
A

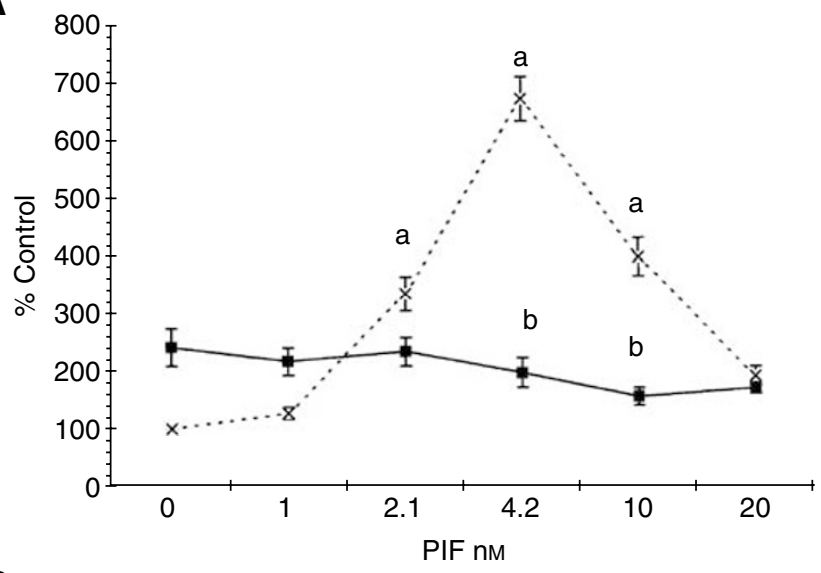

B

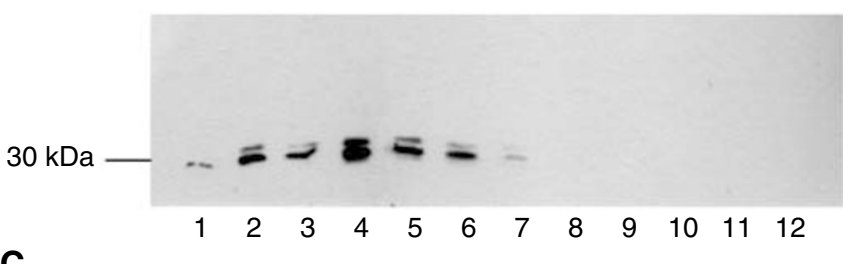

C

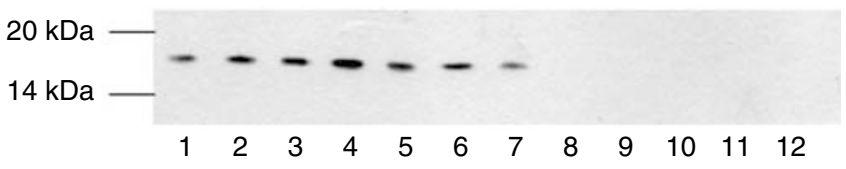

D

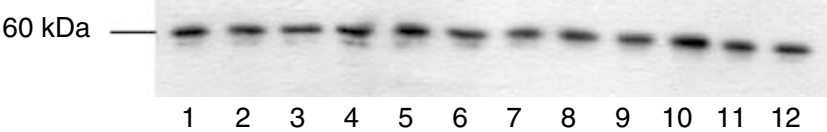

Figure 5 (A) Effect of PIF concentration on the chymotrypsin-like enzyme activity of the proteasome in $\mathrm{C}_{2} \mathrm{C}_{12}$ myotubes in the absence $(x)$ or presence ( $)$ of I0 $\mu \mathrm{M}$ PD98059. The experiment was repeated three times $(n=9)$. Differences from the control are indicated as a, $P<0.001$, while differences from those in the absence of inhibitor are indicated as $b$, $P<0.00$ I. (B-D) Western blots of soluble extracts of $C_{2} C_{12}$ myotubes treated with 0 (lanes I and 7); I.0 (lanes 2 and 8); 2.1 (lanes 3 and 9); 4.2 (lanes 4 and 10); 10 (lanes 5 and II) or 20 nM PIF (lanes 6 and 12) without pretreatment (lanes $\mathrm{I}-6$ ) and after pretreatment for $2 \mathrm{~h}$ in the presence of $10 \mu \mathrm{M}$ PD98059 (lanes 7- 12). Bands were detected using antibody to $20 \mathrm{~S}$ proteasome $\alpha$-subunits $(\mathbf{B})$, E2 ${ }_{14 k}(\mathbf{C})$ or $\beta$-tubulin $(\mathbf{D})$.

known about the intracellular signal transduction pathways involved in gene expression. Although glucocorticoids are know to activate the pathway by opposing the suppression of the transcription of proteasome $\alpha$-subunits by nuclear factor- $\kappa \mathrm{B}$ (NF$\kappa \mathrm{B})(\mathrm{Du}$ et al, 2000) other factors may be involved, since chronic excessive glucocorticoid production, as occurs in Cushing's syndrome, does not increase proteasome expression (Ralliere et al, 1997).

Arachidonic acid is released from cell membranes by the action of phospholipases. $\mathrm{PLA}_{2}$ catalyses the release of fatty acid from the sn-2 position of all membrane phospholipids with the formation of lysophospholipids, while PLC hydrolyses the glycerophosphate ester bond of a variety of phospholipids with the formation of DAG and a phosphate monoester, which can be hydrolysed to AA by DAG lipase (Figure 7). Quinacrine, a nonspecific inhibitor of $\mathrm{PLA}_{2}$, was shown to attenuate PIF-induced proteasome activity, determined by the chymotrypsin-like enzyme activity, and protein degradation, suggesting a role for $\mathrm{PLA}_{2}$ in this process. 
A

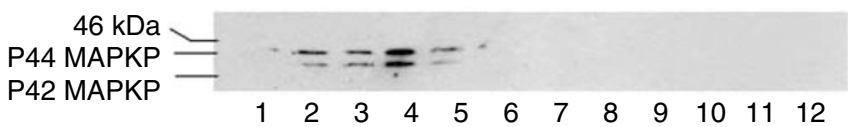

B

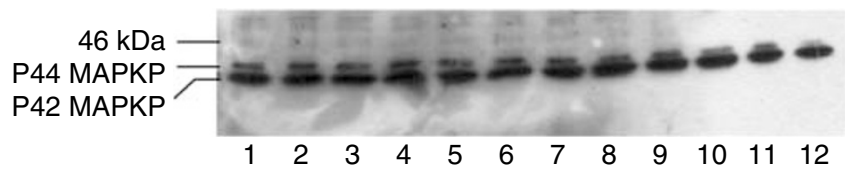

Figure 6 Western blot of active (phosphorylated) ERKI/2 and total ERKI/2 (p44 and p42) (B) in soluble extracts of $\mathrm{C}_{2} \mathrm{C}_{12}$ myotubes treated with 0 (lanes I and 7); I.0 (lanes 2 and 8); 2.1 (lanes 3 and 9); 4.2 (lanes 4 and 10); 10 (lanes 5 and II) or $20 \mathrm{nM}$ PIF (lanes 6 and 12), without pretreatment (lanes $(1-6)$ or after pretreatment for $2 \mathrm{~h}$ in the presence of $10 \mu \mathrm{M}$ PD98059 (lanes 7-12).

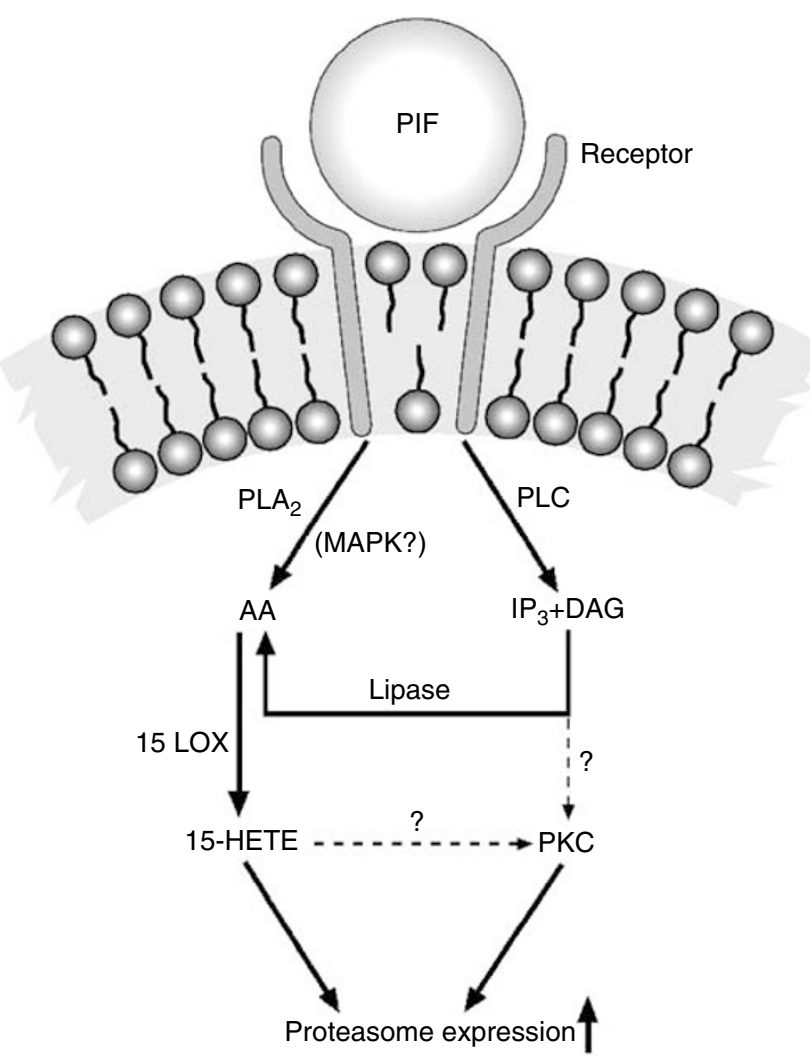

Figure 7 Signal transduction pathways involved in PIF activation of proteasome expression. I5-LOX, I5-lipoxygenase; IP3, inositol I, 4, 5trisphosphate.

Proteolysis-inducing factor was shown to increase the expression of iPLA $_{2}$ at the same concentrations as those inducing the maximal expression of $20 \mathrm{~S}$ proteasome $\alpha$-subunits and protein degradation. The induction of iPLA $_{2}$, proteasome expression and protein degradation by PIF were completely inhibited by trifluroacetyl arachidonic acid, an inhibitor of $\mathrm{PLA}_{2}$. This suggests that either this derivative of $\mathrm{AA}$ is directly downregulating the expression of $\mathrm{iPLA}_{2}$ or that AA itself is responsible for stimulating the expression

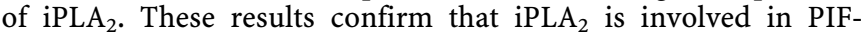
induced proteasome expression and protein degradation through the release of AA from membrane phospholipids. The activation of
$\mathrm{PLA}_{2}$ has been shown to involve MAPK (Lin et al, 1993), suggesting a relationship between the observed activation of MAPK and PLA $_{2}$ activation by PIF.

In addition to $\mathrm{PLA}_{2}$, PLC was also shown to be involved in PIF-induced proteasome expression, as shown by the attenuation of the effect using the PLC inhibitors U73122 and D609, confirming the importance of the release of AA to the overall process. D609 is a selective inhibitor of PC-specific PLC (Sauer et al, 1984) and DAG derived from PC-PLC is suggested to provide a positive feedback signal to PKC (Fallman et al, 1992), which does not appear to cause downregulation of the enzyme (Daiz-Laviada et al, 1990). TNF- $\alpha$ induction of ICAM-1 expression in A549 cells involves the activation of PC-PLC, which induces activation of PKC $\alpha$ and protein tyrosine kinase (Chen et al, 2001). This suggests that the activation of PLC provides a signal for PKC activation, as well as another source of AA. We have recently shown PKC to be involved in PIF-induced proteasome expression (unpublished results), possibly acting as a signal for NF- $\kappa \mathrm{B}$ activation (Vertegaal et al, 2000). TNF- $\alpha$-induced activation of NF$\kappa \mathrm{B}$ was inhibited by selective inhibitors of cytosolic $\mathrm{PLA}_{2}$ (Thommesen et al, 1998), suggesting that this pathway may also be involved in NF- $\kappa \mathrm{B}$-activated gene expression. In addition, PCPLC has been shown to activate protein tyrosine kinase (Chen et al, 2001) and ERK (Toker, 1998). Both the tyrosine kinase inhibitors genistein and tryphostin A23 attenuated PIF-induced proteasome expression, suggesting a role for protein tyrosine kinase in this process.

In mammalian cells, three parallel MAPK pathways have been identified, which includes ERKs, p44 MAPK (ERK1) and p42 MAPK (ERK2), stress-activated protein kinase, c-Jun- $\mathrm{NH}_{2}$-terminal kinases and the p38 MAPK (Chang and Karin, 2001). Extracellular signal-regulated kinases are activated by growth factors acting via MAPK kinase kinase, (such as Raf) and MEKs are involved in both cell proliferation and differentiation (Chang and Karin, 2001). The pathway has been classically viewed to respond to growth factors with the activation of tyrosine kinase receptors acting through small $G$ proteins, such as Ras, leading to the activation of Raf, which then phosphorylates and activates MEK1 and MEK2, which in turn phosphorylate and activate ERK1 and ERK2. The present study shows that PIF induces phosphorylation of ERK1 and ERK2 at the same concentrations as those inducing proteasome expression and that PD98059, a selective inhibitor of MEK (Kültz et al, 1998), attenuated both the PIF-induced activation or ERK1 and ERK2, and the induction of proteasome expression. This suggests that PIF induces proteasome expression through the MAPK pathway. The mechanism by which this occurs is not known, but the MAPK/ERK pathway has been classically viewed to respond to growth factors with the activation of tyrosine kinase receptors acting through small $G$ proteins, such as Ras (Chang and Karin, 2001). The involvement of tyrosine kinase in PIF induction of proteasome expression suggests the operation of a similar pathway. These results provide some information on the intracellular signalling pathways involved in the induction of proteasome expression by PIF (Figure 7).

PIF has been shown to bind to a membrane receptor on skeletal muscle (unpublished observations), although the nature of this receptor and the relationship to $\mathrm{PLA}_{2}$ aret known. Although we have only been able to demonstrate PIF production by cachexiainducing tumours (Cariuk et al, 1997), it may be important during embryonic development. Proteolysis-inducing factor has been shown to be expressed during the embryonic period E8-E9 in mice, peaking during E8.5, a crucial stage in the patterning and eventual development of skeletal muscle (Watchorn et al, 2001). It seems that receptors for PIF required at this stage are still expressed in adult skeletal muscle even in the absence of the agonist. Although PIF production ceases in the adult, the peptide chain, which is devoid of proteolytic activity (Todorov et al, 1996a), is still synthesised as the antimicrobial peptide dermicidin 
(Schittek et al, 2001) or as Y-P30, a neuronal survival peptide (Cunningham et al, 2002). The acquisition by certain tumours of the enzymes necessary to glycosylate this peptide chain leads to PIF expression and breakdown of skeletal muscle.

\section{REFERENCES}

Bodine SC, Latres E, Baumhueter S, Lai VK, Nunez L, Clarke BA, Poueymirou WT, Panaro FJ, Na E, Dharmarajan K, Pan ZQ, Valenzulela DM, DeChiara TM, Stitt TN, Yancopoulos GD, Glass DJ (2001) Identification of ubiquitin ligases required for skeletal muscle atrophy. Science 298: $1704-1708$

Cariuk P, Lorite MJ, Todorov PT, Field WN, Wigmore SJ, Tisdale MJ (1997) Induction of cachexia in mice by a product isolated from the urine of cachectic cancer patients. Br J Cancer 76: 606-613

Chang L, Karin M (2001) Mammalian MAP kinase signalling cascades. Nature 410: $37-40$

Chen C-C, Chou C-Y, Sun Y-T, Huang W-C (2001) Tumor necrosis factor $\alpha$ induced activation of downstream NF- $\kappa \mathrm{B}$ site of the promoter mediates epithelial ICAM-1 expression and monocyte adhesion: ivolvement of PKC $\alpha$, tyrosine kinase and IKK2, but not MAPKs pathway. Cell Signal 13: $543-553$

Cunningham TJ, Jing H, Akerblorn I, Morgan R, Fisher TS, Neveu M (2002) Identification of the human cDNA for new survival/evasion peptide (DSEP): sudies in vitro and in vivo of overexpression by neural cells. Exp Neurol 177: $32-39$

Diaz-Laviada I, Lorrodera P, Diaz-Meco MT, Cornet ME, Guddal PH, Johansen T, Moscat J (1990) Evidence for a role of phosphatidylcholinehydrolysing phospholipase $\mathrm{C}$ in the regulation of protein kinase $\mathrm{C}$ by ras and src oncogenes. EMBO J 9: 3907-3912

Du J, Mitch WE, Wang X, Price SR (2000) Glucocorticoids induce proteasome C3 subunit expression in L6 muscle cells by opposing the suppression of its transcription by NF- $\kappa$ B. J Biol Chem 275: $19661-19666$

Fallman M, Gullberg M, Hellberg C, Anderson T (1992) Complement receptor-mediated phagocytosis is associated with the accumulation of phosphatidylcholine-derived diglyceride in human neutrophils. Involvement of phospholipase D and direct evidence for a positive feedback signal of protein kinase. J Biol Chem 267: 2656-2663

Fan X, Huang X, DaSilva C, Castagna M (1990) Arachidonic acid and related methyl ester mediate protein kinase $\mathrm{C}$ activation in intact platelets through the arachidonate metabolism pathways. Biochem Biophys Res Commun 169: 933-940

Glasser KB, Mobilio D, Chang JY, Senko N (1993) Phospholipase $A_{2}$ enzymes: regulation and inhibition. TiPS 14: $92-98$

Gomes-Marcondes MCC, Smith HJ, Cooper JC, Tisdale MJ (2002) Development of an in vitro model system to investigate the mechanism of muscle protein catabolism induced by proteolysis-inducing factor. Br J Cancer 86: 1628-1633

Hussey HJ, Tisdale MJ (1999) Effect of a cachectic factor on carbohydrate metabolism and attenuation by eicosapentaenoic acid. $\mathrm{Br} \mathrm{J}$ Cancer 80: $1231-1235$

Hussey HJ, Todorov PT, Field WN, Inagaki N, Tanaka Y, Ishitsuka H, Tisdale MJ (2000) Effect of a fluorinated pyrimidine on cachexia and tumour growth in murine cachexia models: relationship with a proteolysis inducing factor. Br J Cancer 83: 56-62

Kultz D, Madhany S, Burg MB (1998) Hyperosmolality causes growth arrest of murine kidney cells. Induction of GADD45 and GADD153 by osmosensing via stress-activated protein kinase 2. J Biol Chem 273: 13645 - 13651

Lecker SH, Solomon V, Mitch WE, Goldberg AL (1999) Muscle protein breakdown and the critical role of the ubiquitin - proteasome pathway in normal and disease states. J Nutr 129: 227S-237S

Lin L, Wartmann M, Lin AY, Knopf J L, Seth A, Davis RJ (1993) cPLA 2 is phosphorylated and activated by MAP kinase. Cell 72: 269-278

Lorite MJ, Thompson MG, Drake JL, Carling G, Tisdale MJ (1998) Mechanism of muscle protein degradation induced by a cancer cachectic factor. $\mathrm{Br}$ J Cancer 78: $850-856$

\section{ACKNOWLEDGEMENT}

This work has been supported by a grant from the Lustgarten Foundation for Pancreatic Cancer Research.

Lorite MJ, Smith HJ, Arnold JA, Morris A, Thompson MG, Tisdale M (2001) Activation of ATP-ubiquitin-dependent proteolysis in skeletal muscle in vivo and murine myoblasts in vitro by a proteolysis-inducing factor (PIF). Br J Cancer 85: 297-302

Nakamura S, Nishizuka Y (1994) Lipid mediators and protein kinase C activation for the intracellular signaling network. J Biochem (Tokyo) 115: $1029-1054$

Orino E, Tanaka K, Tamura T, Sone S, Ogura T, Ichihara A (1991) ATPdependent reversible association of proteasomes with multiple protein components to form $26 \mathrm{~S}$ complexes that degrade ubiquitinated proteins in human HL-60 cells. FEBS Lett 284: 206-210

Rajapurohitam V, Morales CR, El-Alfy M, Lefrancois S, Bedard N, Wing SS (1999) Activation of a UBC4-dependent pathway of ubiquitin conjugation during postnatal development of the rat testis. Dev Biol 212: $217-228$

Ralliere C, Tauveron I, Taillandier D, Guy L, Boiteux JP, Giraud B, Attaix D, Thieblot P (1997) Glucocorticoids do not regulate the expression of proteolytic genes in skeletal muscle from Cushing's syndrome patients. J Clin Endocrinol Metab 82: 161 - 164

Sauer G, Amtmann E, Melber K, Knapp A, Muller K, Hummel K, Scherm A (1984) DNA and RNA virus species are inhibited by xanthates, a class of antiviral compounds with unique properties. Proc Natl Acad Sci USA 81: $3263-3267$

Schittek B, Hipfel R, Sauer B, Bauer J, Kalbacher H, Stevanovic S, Schirle M, Schroeder K, Blin N, Meier F, Rassner G, Garbe C (2001) Dermicidin: a novel human antibiotic peptide secreted by sweat glands. Nat Immunol 2: $1133-1137$

Smith HJ, Lorite MJ, Tisdale MJ (1999) Effect of a cancer cachectic factor on protein synthesis/degradation in murine $\mathrm{C}_{2} \mathrm{C}_{12}$ myoblasts: modulation by eicosapentaenoic acid. Cancer Res 59: 5507-5513

Temparis S, Asensi M, Taillandier D, Aurousseau E, Larbaud D, Obled A, Bechet D, Ferrara M, Estrela JM, Attaix D (1994) Increased ATP ubiquitin-dependent proteolysis in skeletal muscles of tumor-bearing rats. Cancer Res 54: 5568-5573

Thommesen L, Sjursen W, Gasvik K, Hanssen W, Brekke O-L, Skatteboe L, Holmeide AK, Espevik T, Johansen B, Laegreid A (1998) Selective inhibitors of cytosolic or secretory phospholipase $\mathrm{A}_{2}$ block TNF-induced activation of transcription factor nuclear factor $\kappa \mathrm{B}$ and expression of ICAM-1. J Immunol 161: 3421 - 3430

Todorov P, Cariuk P, McDevitt T, Coles B, Fearon K, Tisdale M (1996a) Characterization of a cancer cachectic factor. Nature 379: 739-742

Todorov PT, McDevitt TM, Cariuk P, Coles B, Deacon M, Tisdale MJ (1996b) Induction of muscle protein degradation and weight loss by a tumor product. Cancer Res 56: 1256-1261

Toker A (1998) Signaling through protein kinase C. Front Biosci 3: $1134-1147$

Vertegaal AC, Kuiperji HB, Yamaoka S, Courtois G, van der Eb AJ, Zantema A (2000) Protein kinase C-alpha is an upstream activator of the IkappaB kinase complex in the TPA signal transduction pathway of NF-kappaB in U2OS cells. Cell Signal 12: 759-769

Watchorn TM, Waddell ID, Dowidar N, Ross JA (2001) Proteolysisinducing factor regulates hepatic gene expression via the transcription factors NF- $\kappa$ B and STAT 3. FASEB J 15: $562-564$

Wigmore SJ, Todorov PT, Barber MD, Ross JA, Tisdale MJ, Fearon KCH (2000) Characteristics of patients with pancreatic cancer expressing a novel cancer cachectic factor. Br J Surg 87: 53-58

Yule DI, Williams JA (1992) U73122 inhibits $\mathrm{Ca}^{2+}$ oscillations in response to cholecystokinin and carbachol but not JMV-180 in rat pancreatic acinar cells. J Biol Chem 267: $13830-13835$ 